\title{
SIX NEW HOVERFLY SPECIES (DIPTERA: SYRPHIDAE) IN THE FAUNA OF SERBIA
}

\author{
Mihailo Vujić*, Milan Đurić, Ivan Tot \\ HabiProt, Cankareva 9/13, 21000 Novi Sad, Serbia \\ *Corresponding author: mihailovujic01@gmail.com \\ (Received March 28, 2021; Accepted May 10, 2021)
}

\begin{abstract}
During a survey conducted from 2018 to 2021, six hoverfly species were registered on the territory of Serbia for the first time: Chalcosyrphus pannonicus (Oldenberg, 1916), Chrysogaster coemiteriorum (Linnaeus, 1758), Eristalinus taeniops (Wiedemann, 1818), Melanogaster parumplicata (Loew, 1840), Merodon testaceus Sack, 1913 and Psilota atra (Fallén, 1817). Data about new records are presented.
\end{abstract}

Keywords: biodiversity, Chalcosyrphus, Chrysogaster, Eristalinus, Melanogaster, Merodon, Psilota.

\section{INTRODUCTION}

Hoverflies (Syrphidae) are a large family of Diptera, and European fauna comprises more than 950 species (SPEIGHT, 2020). Hoverfly fauna in Serbia is well-studied, with more than 400 registered species (VUJIĆ et al., 2018; VAN STEENIS et al., 2019; VUJIĆ, 2020a,b; VUJIĆ and Tот, 2020). They are ecologically very important group of flies that perform ecosystem services, such as pollination of flowering plants, nutrient recycling and predation on plant pests (ROTHERAY and GILBERT, 2011).

\section{MATERIAL AND METHODS}

A survey was conducted from 2018 to 2021, at many localities on the territory of Serbia (Tab. 1). Specimens were collected on the flowers, or during the resting on the stones, using entomological net. Collected specimens were prepared by standard procedure, after which they were identified using the keys, figures and descriptions provided in VAN VEEN (2004), VUJIĆ et al. (2013) and SPEIGHT and SARTHOU (2017). All records are stored into Alciphron database of Serbian insects (VUJIĆ, 2020a). 
Table 1. Localities where new hoverfly species for the fauna of Serbia were found.

\begin{tabular}{llc}
\hline Locality & District & Coordinates \\
\hline Deliblato Sands & South Banat & N44 52 21 E21 01 23 \\
Vrčin, Donja Mala & City of Belgrade & N44 40 36 E20 36 28 \\
Vrčin, Lovački dom & City of Belgrade & N44 40 25 E20 37 22 \\
Vlasina, Dejanova Reka & Pčinja & N42 40 29 E22 23 11 \\
Vlasina, Srednja Reka & Pčinja & N42 45 11 E22 17 30 \\
Vlasina, Vlasina River & Pčinja & N42 45 50 E22 19 07 \\
Vlasina, Teskovo - Čuka & Pčinja & N42 46 42 E22 18 49 \\
Preševo, Miratovac & Pčinja & N42 16 16 E21 38 35 \\
Pčinja Valley & Pčinja & N42 19 33 E21 52 40 \\
Rujen Mt., Sebrat & Pčinja & N42 21 39 E21 49 37 \\
\hline
\end{tabular}

\section{RESULTS}

In total, six species from subfamily Eristalinae were registered as new for the fauna of Serbia.

Chalcosyrphus pannonicus Oldenberg, 1916 (Fig. 1A)

Material examined: Vlasina, Teskovo - Cuka, N42 4642 E22 18 49, UTM: FN03, 30.07.2020. leg. M. Vujić.

Notes: Just a single female specimen was collected on Pastinaca sativa flowers.

Chrysogaster coemiteriorum (Linnaeus, 1758) (Fig. 1B)

Material examined: Deliblato Sands, N44 5221 E21 01 23, UTM: EQ06, 01.09.2020. leg. M. Vujić.

Notes: Three female specimens were collected on flowers of Daucus carota and an unidentified white flowering umbellifer.

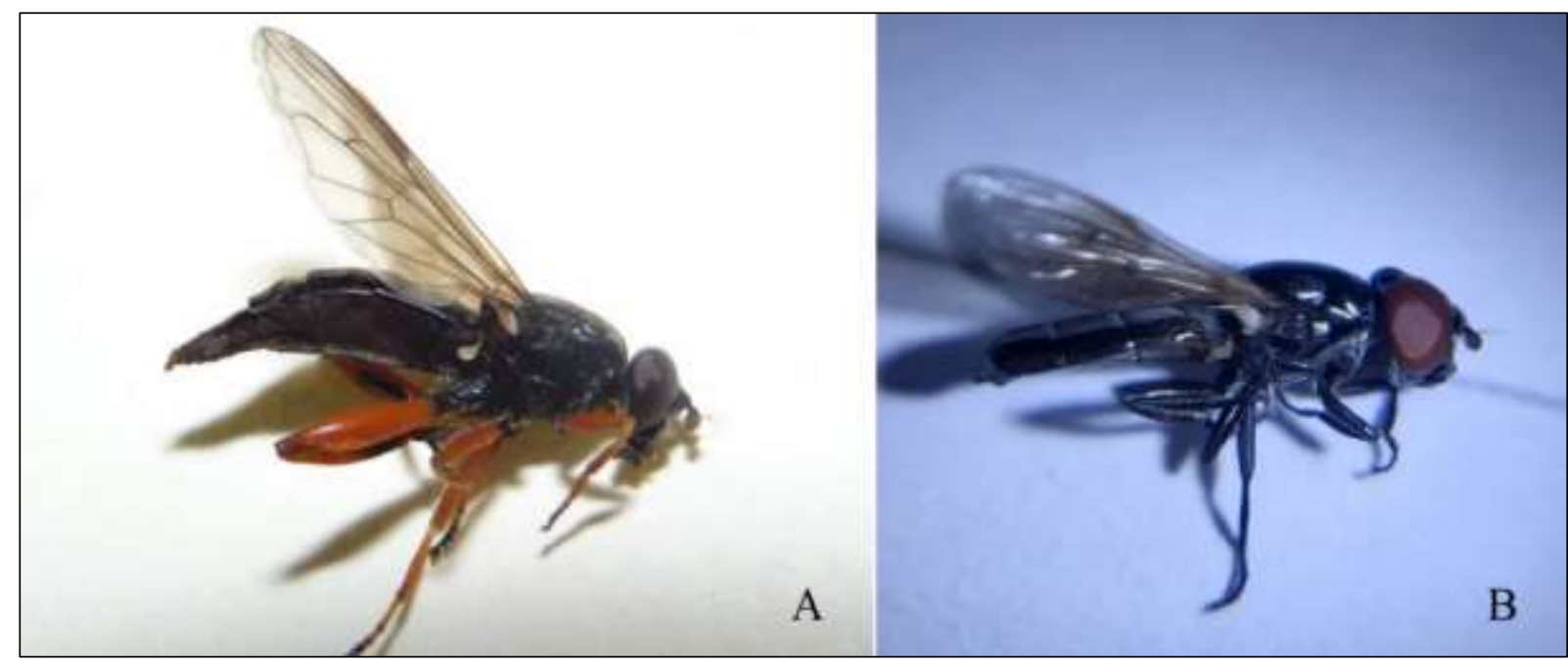

Figure 1. A - Chalcosyrphus pannonicus Oldenberg, 1916: habitus of female, lateral view; B - Chrysogaster coemiteriorum (Linnaeus, 1758): habitus of female, lateral view.

(Photos: M. Vujić, 2020) 
Eristalinus taeniops (Wiedemann, 1818) (Fig. 2)

Material examined: Belgrade, Vrčin, Donja Mala, N44 4036 E20 36 28, UTM: DQ64, 10.11.2018. leg. M. Vujić.

Notes: One female specimen was collected on flower of cultivated purple Chrysanthemum, in a private garden. Recording of this Mediterranean and thermophilous species is very unexpected, so specimen probably migrated due to unusually warm autumn in Serbia in 2018. In the same period, Mediterranean true bug Caenocoris nerii (Germar, 1847) was recorded in the same garden, also on Chrysanthemum flowers (ŠEAT et al., 2019).

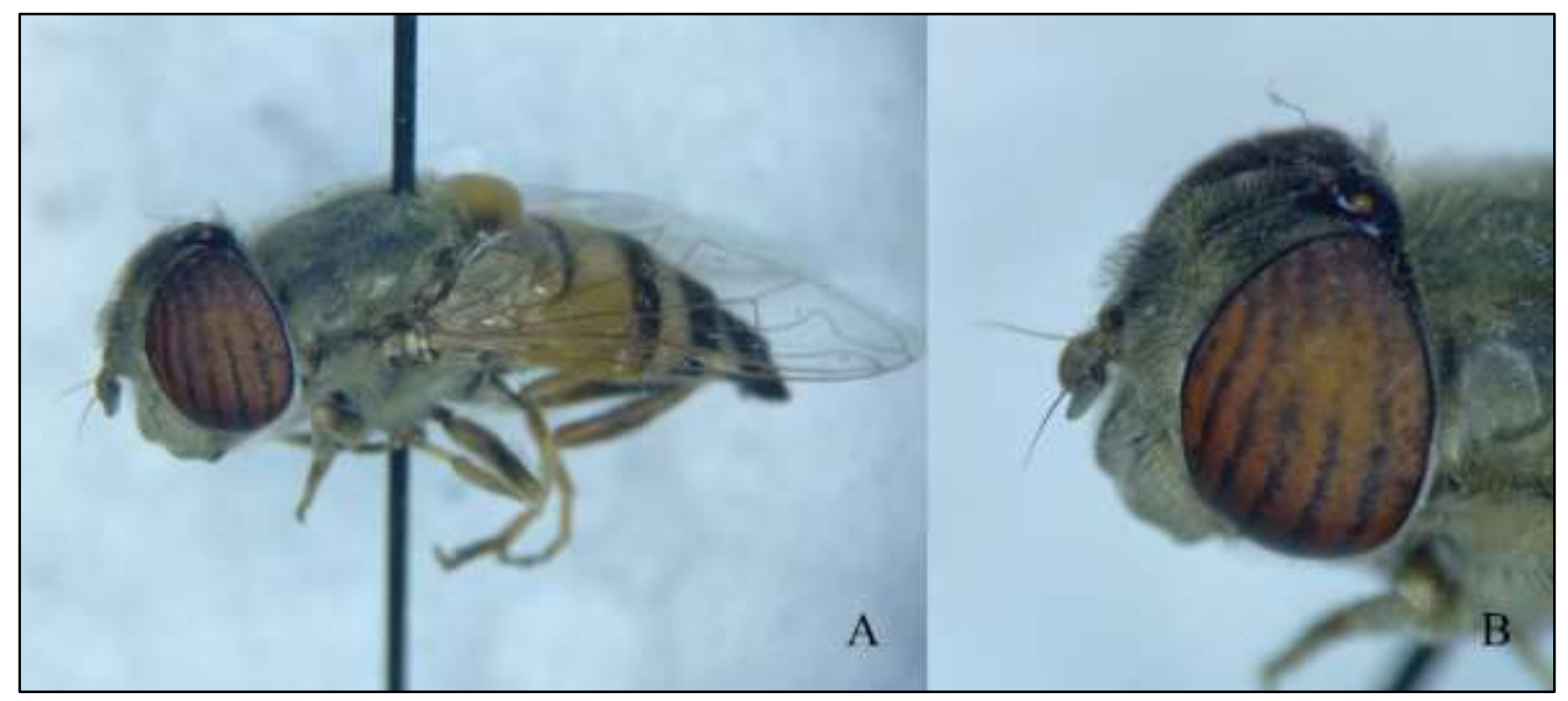

Figure 2. Eristalinus taeniops (Wiedemann, 1818): A - habitus of female, lateral view; B - head of female. (Photo: M. Vujić, 2021)

\section{Melanogaster parumplicata (Loew, 1840) (Fig. 3)}

Material examined: Vlasina, Dejanova Reka, N42 4029 E22 23 11, UTM: FN12, 26.05.2019. leg. M. Vujić \& T. Tot, 31.05.2021. leg. M. Vujić; Vlasina, Srednja Reka, N42 4511 E22 17 30, UTM: FN03, 28.05.2019. leg. M. Vujić \& T. Tot; Vlasina, Vlasina River, N42 4550 E22 19 07, UTM: FN03, 27.09.2020. leg. M. Vujić.

Notes: Several specimens were collected at three localities at Vlasina plateau, on flowers of Achillea millefolium, Ranunculus sp. and unidentified white flowering umbellifers. All the specimens were caught in wet meadownear rivers or streams, in wet meadows. Fauna of some groups of insects, such as butterflies, orthopterans, true bugs, dragonflies and damselflies, at Vlasina plateau is well-studied (SKEJO and IVKOVIĆ, 2015; TOT et al., 2015; VuJIĆ et al., 2016; Tot et al., 2017; ŠEAT, 2018; TOT et al., 2018; ŽIKIĆ et al., 2018; ĐukIĆ et al., 2019; Protić and NADAŽDIN, 2020; VUJIĆ et al., 2020). Recording of these species, together with $C h$. pannonicus and already published records of Arctophila bequaerti Hervé-Bazin, 1913 strongly indicates importance and faunistical potential of these habitats for further research.

\section{Merodon testaceus Sack, 1913 (Fig. 4)}

Material examined: Preševo, Miratovac, N42 1616 E21 38 35, UTM: EM58, 09.05.2020. leg. M. Vujić; Pčinja Valley, N42 1933 E21 52 40, UTM: EM78, 17.05.2021. leg. M. Vujić; Rujen Mt., Sebrat, N42 2139 E21 49 37, UTM: EM69, 19.05.2021. leg. M. Đurić.

Notes: Five male specimens were collected on the rocks, in dry meadows or on rocky slopes, at three localities in southern part of country. The localities where this species was recorded are xerothermic and Mediterranean-influenced, such as Miratovac (Fig. 5), many thermophilous and Mediterranean insects have been found there: butterflies Anthocharis gruneri Herrich- 
Schäffer, 1851 and Pyrgus cinarae (Rambur, 1839), bush-cricket Bradyporus dasypus (Illiger, 1800), longhorn beetle Blepisanis vittipennis (Reiche, 1877), weevil Brachycerus sinuatus Olivier, 1807 etc. (ĐurĐEVIĆ and Đurić, 2011; PopOVIĆ and MiLENKOVIĆ, 2012; Popović et al., 2014; IVKOVIĆ et al., 2016; PEŠIĆ et al., 2020).

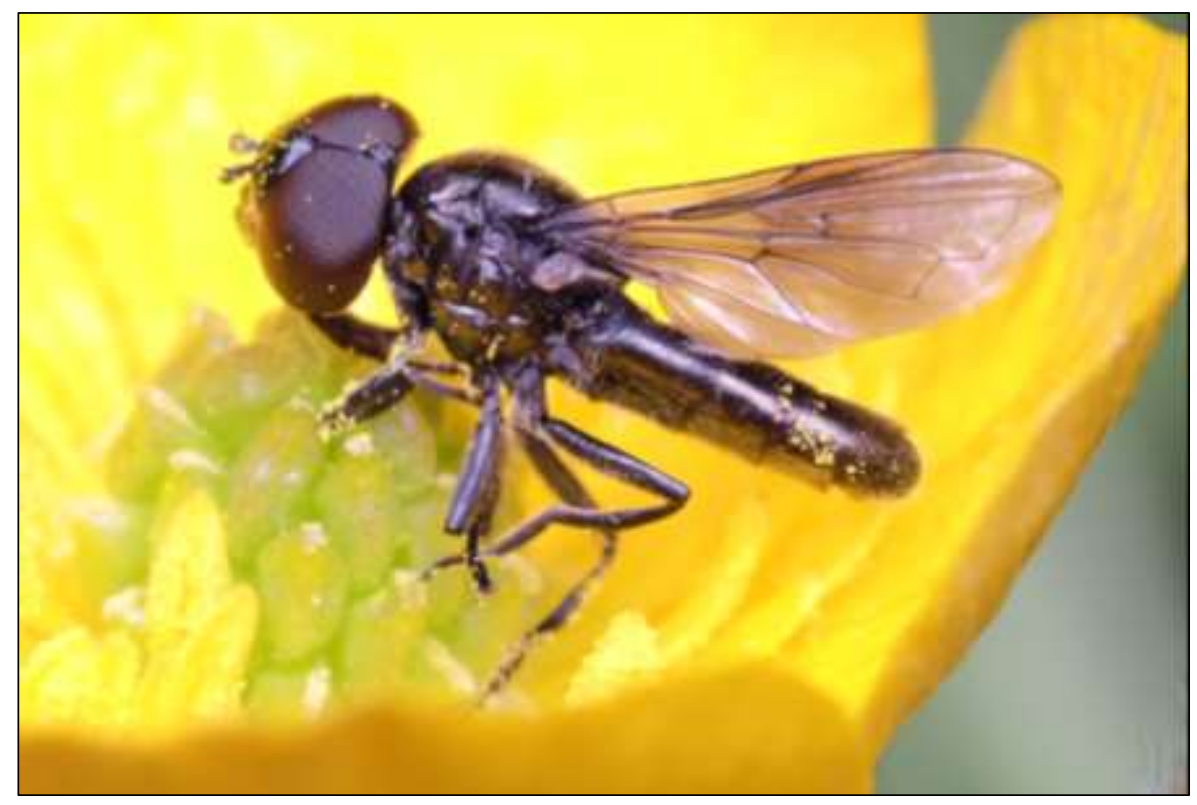

Figure 3. Melanogaster parumplicata (Loew, 1840), habitus of male, lateral view. (Photo: I. Parenta, 2021)

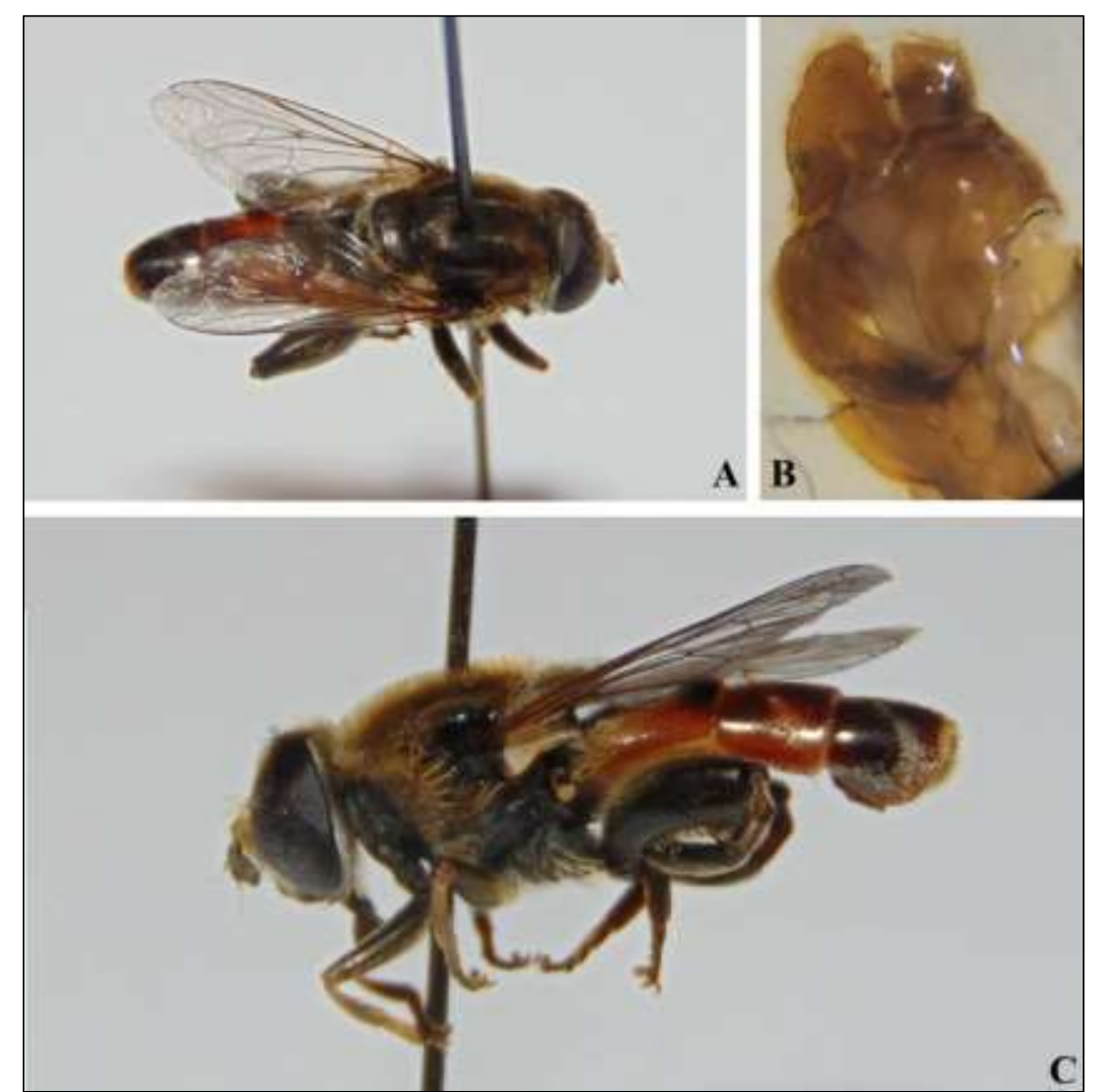

Figure 4. Merodon testaceus Sack, 1913; A, C - habitus of male (A - dorsal view; C - lateral view); B - terminalia of male. (Photo: M. Vujić, 2020) 




Figure 5. Miratovac, locality where Merodon testaceus Sack, 1913 was collected. (Photo: M. Vujić)

Psilota atra (Fallén, 1817) (Fig. 6)

Material examined: Belgrade, Vrčin, Lovački dom, N44 4025 E20 37 22, UTM: DQ74, 2.5.2021. leg. M. Vujić.

Notes: One female specimen was caught on a mud, under the white willow (Salix alba) tree.



Figure 6. Psilota atra (Fallén, 1817); A - habitus of female, lateral view; B - hind femur of female. (Photo: M. Vujić, 2021) 


\section{Acknowledgments}

The authors would like to thank Igor Parenta for photo presented as Figure 3.

\section{References:}

[1] Đukić, A., Mirić, R., Skejo, J., RAJKov, S., Tot, I. (2019): Survey on the damselfly and dragonfly fauna (Insecta: Odonata) on the Landscape of Outstanding Features "Vlasina". Kragujevac Journal of Science 41: 133-146. doi: 10.5937/KgJSci1941133D

[2] ĐurĐević, A., Đurić, M. (2011): Blepisanis vittipennis (Reiche 1877) (Coleoptera: Cerambycidae), a new longhorn beetle for Serbia. Biologica Nyssana 2 (2): 129-130.

[3] Ivković, R.S., Popović, M., Pavićević, M.D., Franeta, F., Horvat, L.L., Đurić, M. (2016): Distribution and Decline of Bradyporus dasypus (Illiger, 1800) (Orthoptera: Tettigoniidae) in Serbia and the Republic of Macedonia. Acta Zoologica Bulgarica 68 (4): 541-546.

[4] PeŠIĆ, S., Đurić, M., NADAŽDIN, B., Tot, I. (2020): First record of Brachycerus sinuatus Olivier, 1807 (Coleoptera: Curculionidae) in Serbia. Kragujevac Journal of Science 42: 161-166. doi: 10.5937/KgJSci2042161P

[5] Popović, M., Milenković, M. (2012): First record of Anthocharis gruneri for Serbia (Lepidoptera: Pieridae). Phegea (Leefdaal, Belgium) 40 (1b): 37-38.

[6] Popović, M., Radevski, Đ., Miljević, M., Đurić, M. (2014): First records of Pyrgus cinarae (Lepidoptera: Hesperidae) in Serbia. Acta entomologica serbica 19 (1/2): 45-51.

[7] Protić, LJ., NAdAŽdin, B. (2019): Aquatic and Semiaquatic Heteroptera of Serbia. Bulletin of the Natural History Museum, Belgrade 12: 179-207. doi: 10.5937/bnhmb1912179P

[8] Rotheray, G. E., GiLbert, F. (2011): The natural history of hoverflies. Forest Text, Ceredigion, UK: $334 \mathrm{pp}$.

[9] Skejo, J., IVković, S. (2015): Chorthippus bornhalmi in the heart of the Balkans (Acrididae: Gomphocerinae). Articulata 30: 81-90.

[10] Speight, M.C.D., SARTHOU, J.-P. (2017): StN keys for the identification of the European species of various genera of Syrphidae 2017. Syrph the Net, the database of European Syrphidae (Diptera), vol. 99. Syrph the Net publications, Dublin: 139 pp.

[11] Speight, M.C.D. (2020): Species accounts of European Syrphidae, 2020. Syrph the Net, the database of European Syrphidae (Diptera), vol. 104. Syrph the Net publications, Dublin: 314 pp.

[12] ŠEAT, J. (2018): Contribution to the knowledge on true bugs (Insecta: Heteroptera) of Vlasina. Zaštita prirode 67 (1-2): 43-54. doi: 10.5937/ZasPri1702043S

[13] ŠEAT, J., Vujić, M., NADAŽDin, B. (2019): New faunal data on true bugs (Heteroptera) in Serbia. Acta entomologica serbica 24 (1): 95-99. doi: 10.5281/zenodo.2648459

[14] Tot, I., ĐuRIĆ, M., POPOVIĆ, M. (2017): Butterflies of Vlasina. JP Direkcija za zemljište i puteve opštine Surdulica i HabiProt: 152 pp. 
[15] Tot, I., Slacki, A., Đurić, M., Popović, M. (2015): Butterflies of the Vlasina region in southeast Serbia (Lepidoptera: Papilionoidea). Acta entomologica serbica 20: 117-135. doi: $10.5281 /$ zenodo.45393

[16] Tot, T., Vujić, M., Likov, L., Nedeljković, Z., Radenković, S., Vujić, A. (2018): Hoverfly fauna (Diptera: Syrphidae) of the Landscape of Outstanding Features "Vlasina". Acta entomologica serbica 23 (1): 33-50. doi: 10.5281/zenodo.1306741

[17] Van Steenis, J., Nedeljković, Z., Tot, T., VAn der Ent, L-J., Van Eck, A., MazÁneK, L., ŠEBiĆ, A., RADENKOVIĆ, S., VuJiĆ, A. (2019): New records of hoverflies (Diptera: Syrphidae) and the rediscovery of Primocerioides regale Violovitsh for the fauna of Serbia. Biologia Serbica 41 (1): 94-103. doi: 10.5281/zenodo.3526446

[18] Van VeEn, M. (2004): Hoverflies of Northwest Europe: identification keys to the Syrphidae. KNNV Publishing, Utrecht: $256 \mathrm{pp}$.

[19] Vujić, A., Radenković, S., Likov, L., Trifunov, S., Nikolić, T. (2013): Three new species of the Merodon nigritarsis group (Diptera: Syrphidae) from the Middle East. Zootaxa 3640 (3): 442-464. doi: 10.11646/zootaxa.3640.3.7

[20] Vujić, A., Radenković, S., Nedeljković, Z., Šımić, S. (2018): A new check list of hoverflies (Diptera: Syrphidae) of the Republic of Serbia. Matica srpska Journal for Natural Science 135: 7-51. doi: 10.2298/ZMSPN1835007V

[21] Vujić, M., Tot, I. (2020): Brachyopa bimaculosa Doczkal \& Dziock 2004 and Callicera fagesii Guérin-Méneville, 1844, two new hoverflies (Diptera: Syrphidae) in the fauna of Serbia. Acta entomologica slovenica 28 (1): 75-79.

[22] VuJić, M. (2020a): Alciphron - baza podataka o insektima Srbije: Syrphidae. HabiProt. Available at: https://alciphron.habiprot.org.rs (Accessed on 28 November 2020).

[23] VuJić, M. (2020b): Cheilosia herculana Brădescu, 1982, a new hoverfly (Diptera: Syrphidae) for the fauna of Serbia. Acta entomologica serbica 25 (1): 87-90. doi: 10.5281/zenodo.3661000

[24] Vujić, M., Đurić, M., Tot, I. (2020): New records and distribution of species from genus Arctophila Schiner, 1860 (Diptera: Syrphidae: Eristalinae) in Serbia. Kragujevac Journal of Science 42: 151-160. doi: 10.5937/KgJSci2042151V

[25] Vujić, M., Tot, T., NedeljKović, Z. (2016): Arctophila bequaerti Hervé-Bazin (Diptera: Syrphidae), new to the Serbian fauna. Studia dipterologica, 23 (2): 162-164.

[26] Žikić, V., Stanković, S.S., Tschorsnig, H.-P., Monasterio León, Y., De Freina, J.J. (2018): Parasitoids of Heterogynis Rambur (Lepidoptera: Zygaenoidea, Heterogynidae). Archives of biological sciences 70 (4): 749-755. doi: 10.2298/ABS180709039Z 